\title{
The Technology of Forming the Students' Research Competence in the Process of Learning a Foreign Language
}

\author{
Olga Vladimirovna Lopatina ${ }^{1}$, Guzel Rafkatyevna Fassakhova ${ }^{2}$, Leysan Atlasovna Akhmetova ${ }^{3}$, Rinat \\ Gabdullovich Gatin $^{3}$, Alfiya Shaukatovna Yarullina ${ }^{3}$, Svetlana Radanisovna Nikishina ${ }^{3}$ \& Elmira Robertovna \\ Khairullina $^{4}$ \\ ${ }^{1}$ Kazan National Research Technical University named after A.N. Tupolev, Russia \\ ${ }^{2}$ Kazan State Agrarian University, Russia \\ ${ }^{3}$ Kazan Federal University, Russia \\ ${ }^{4}$ Kazan National Research Technological University, Russia \\ Correspondence: Olga Vladimirovna Lopatina, Kazan National Research Technical University named after \\ A.N. Tupolev, Kazan, K. Marks Street, 10, Tatarstan, 420111, Russia. E-mail: alfkazan@mail.ru
}

Received: September 25, 2014 Accepted: December 6, 2014 Online Published: December 30 , 2014

doi:10.5539/ass.v11n $7 \mathrm{p} 152$

URL: http://dx.doi.org/10.5539/ass.v11n7p152

\begin{abstract}
The research issue appears important as today's system of professional education requires an optimal structure of the academic disciplines intended for the students' research and creative abilities development. In this regard, the purpose of the article is to develop a technique for forming the students' research competence in the process of learning a foreign language. The flagship approaches to the development of this technology have become the research and modular competence-based approaches. The article describes the technology of the students' research competence formation in the process of learning a foreign language, the proposed stages of which are universal and can be also used in the formation of the students' communicative competence, while the submitted steps are particularly aimed at the formation of the students' research competence in the process of learning a foreign language. The materials of this article may be of value to the foreign language teachers while selecting and structuring the foreign language learning curriculum aimed at the formation of the research competence among the students of higher professional schools.
\end{abstract}

Keywords: research competence, the "Foreign Language" discipline, technology, higher professional school.

\section{Introduction}

The processes of globalization and integration of Russia into the world educational space lead to the renewal of the national higher professional education that requires high responsibility for the quality of the educational services.

The globalization of education is embodied primarily in increasing academic mobility, the priority of the international research, the extension of the international contacts and joint international projects (Berezhnova \& Krajewski, 2006; Obukhov, 1999). These changes impose a certain responsibility on teachers and students - the future professionals of postindustrial civilization, the dynamism of which has stipulated the necessity to modernize the education curriculum in order to provide such valuable knowledge that would allow them to keep ahead of the organization renovation in their future professional activity. In this regard the objective of educating a specialist whose training would meet international requirements, and who would be able to solve the urgent problems of post-industrial society to enhance its financial revenue and strengthen its economic position in the international arena appears one of the most important issues among other objectives of the Russian Federation higher schooling (Bim, 2005; Giniatullin, 1990). This effect can be achieved by targeting future specialists' training at the development of their mobility and competitiveness thus enabling them to maximize their abilities.

The aforementioned circumstances have stipulated the search for solutions of the following problems:

- First, the Russian economy during the last decade has undergone essential changes, but these changes have not yet ended, as the technology renewal in the most advanced sectors of the economy occurs every two or three 
years, and therefore the future specialist in the field of economy should be able not only to objectively analyze the current situation, but also to renew and enrich his knowledge while exploring the new fields of activities in order to forecast the economy changes and respond to dynamic and non-linear transformation well-judged (Lopatina, 2009);

- Second, the intellectualization of the economy raises fundamentally new problems in training the specialists in economics, wherefore the future competitive economist should clearly realize the role of the research component in his education as well as the research skills in his future professional activity, as the abundance of the graduates with economic diplomas in the labor market does not solve the problem of the acute shortage in the qualified professionals who are able to creatively solve professional problems by methods of scientific cognition to achieve positive economic reforms in Russia (Lopatina \& Ratner, 2011; Masalimova et al., 2014);

- Third, the widening scope of international contacts between Russian and foreign companies, corporations and businesses that need social, professional and academic mobility of the subjects of this sphere imposes new requirements to both the research and foreign language competences of the future specialist in economics capable of building cross-cultural scientific relations, participating in international conferences and symposiums, studying international experience in the field of the acquired specialty in order to choose the correct behavioral strategies to ensure the effectiveness of his cross-cultural communication (Karpov, 2004; Morozova \& Fadeev, 2007);

- Fourth, there is the necessity for a structure of the academic disciplines optimal for the development of investigational and creative abilities of the students and which is similar to the structure of a scientific research, as well as the new organizational forms that would involve into the foreign language learning curriculum not only the professionally-oriented educational material, but also philosophical, sociological, economic, psychological ones required for the professional activity of a specialist in economics to enable him to acquire the skills of carrying out a scientific work and implementing the achieved results adapted to the present condition of the society and economy in the process of renovation (Voivoda, 2009).

The aforementioned circumstances make it urgent to find the effective approaches that would involve students into vigorous conscious research activities performed in a foreign language.

\section{Materials and Methods}

The hypothesis of the study is based on the assumption that the formation of the students' research competence will be effective in the process of learning a foreign language if its technology including analytical-prognostic, motivational-orienting, designing, organizational-methodical, and corrective-implementation stages has been designed and implemented.

To test this hypothesis the following methods have been applied:

- theoretical: the analysis of the psychological and educational literature on the problem of the study; specification and generalization, idealization and extrapolation; investigation and generalization of the innovative teaching experience; the subject and curriculum analysis of the national and foreign educational programs, textbooks and manuals in a foreign language;

- empirical: the investigation of the experience of the foreign languages university departments; psycho-pedagogical, sociological methods of data collection (teacher observation, questionnaires and interviews, the study of teaching experience, the analysis of the students' and teachers' performance, diagnostic techniques); pedagogical experiment;

- statistics: the statistic analysis and interpretation of the research results, its mathematical processing and others.

The experimental work to verify the effectiveness of this technology has been conducted in "Kazan National Research Technical University named after A.N.Tupolev" and "Kazan Federal University." The pilot study involved 197 students of the first and second courses: the experimental group - 101 students, the control group 96 students.

\section{Results}

The technology of the students' research competence formation in the process of learning a foreign language is a complex, multi-level object that includes consistent, successive stages and steps:

1. The analytical-prognostic stage provides the analysis of the tendencies in the economic education development; the analysis of the requirements of the State Educational Standard of Higher Professional Education to the level of professional competence (including research competence) of the future specialists in economics; the analysis of the modern requirements for the students' proficiency in a foreign language in the 
context of increasing academic mobility; clarification and specification of the structural components of the research competence formation in the process of learning a foreign language; the analysis of the national and international experience in using innovative technologies while forming the students' research competence; the study of the employers' opinions on the investigated topic; forecasting the results of the research activity.

2. The motivational-orienting stage involves identifying of the cognitive-motivational potential of the "Foreign Language" discipline, which would contribute to the appearance and development of a sustained interest in research activities in the process of learning a foreign language; formation of a need and skills for active exploration work of a scientific character; exposure to the leading concepts of research activities, various methods of scientific cognition as well as a specific vocabulary in a foreign language.

3. The designing stage involves reviewing the foreign language curriculum aimed at the formation of the research competence of the students in economics; identification of the course external relations through its interdisciplinary connections; the choice and development of the exercises of professional research character for the students' unsupervised work; the development of the check-up assignments to identify the dynamics of the students' research competence formation in the process of a foreign language acquisition.

4. The organizational-methodical stage involves organizing the educational material of the "Foreign Language" discipline using innovative teaching technologies, including such forms and methods of teaching that promote creativity and intellection; wide use of modern telecommunication and computer technologies and tools in the educational process; the innovative forms of classroom teaching, the organization of independent work, research, practices, working over innovative projects.

5. The corrective-implementation stage discusses the contents of the developed foreign language learning curriculum aimed at the formation of the research competence of the students in economics at various levels, particularly at the faculty meetings, seminars, scientific conferences, etc.; identifying the students' level of the research competence in the process of learning a foreign language; identifying the causes and conditions that prevent formation of the research competence of the students of the university economics specialties; the collection and analysis of all incoming information and, if necessary, its further development by the discipline curriculum developers; the development of an implementation algorithm of educational and methodological support for the higher school educational process; the use of educational and methodological support aimed at the formation of the students' research competence in the process of learning a foreign language in higher educational institutions.

The submitted technology of the research competence formation among the the students in economics in the process of learning a foreign language presents the design stages that are universal and can be used while forming the students' communicative competence, and the presented design steps directly aim at the formation of their research competence.

At the ascertaining stage of the experiment the authors have performed the analysis of the regulations, curricula, educational programs, textbooks and manuals of the subject "Foreign Language" written by both national and foreign authors; developed a curriculum for a foreign language study, a study guide for the students, a methodological manual for the teachers aimed at forming the research competence of the students of university economics specialties in the process of learning a foreign language; developed an algorithm of the experimental work, diagnostic techniques for its implementation, a set of criteria (motivational-axiological, cognitive, communicative, procedural-activity, reflexive-analytical) and their performance.

These criteria have been measured within the relevant provisions. The assessment of the cognitive component was carried out according to a specially developed tests that had previously been tested for validity. The motivational-axiological component was estimated according to the developed questionnaire; the proceduralactivity component was estimated in the course of the students' participation in the conferences held in a foreign language; the communicative one - by observing the discussions and business games; the reflective - analytical was diagnosed in the course of the research projects, such as "A Foreign Trade contract", "The comparative analysis of the national and foreign investment." The students were offered to analyze the research component of the project and the applicable scope of the acquired skills.

The analysis of the components of the research competence has revealed the divergence in formation of the particular constituents. This has allowed us to adjust the foreign language learning curriculum in order to improve the development of the immature components of the research competence.

To assess the overall level of the research competence development we offered the students to self- assess it within the developed levels and criteria. The individual self-ratings were verified by the teachers-experts. The 
students' self-rating figures and the experts' evaluations have corresponded. Table 1 shows the distribution of the students according to the level of the research competence development before the formative phase of the experiment.

Table 1. The distribution of the students according to the level of the research competence formation before the formative stage of the experiment

\begin{tabular}{lccc}
\hline Groups & \multicolumn{2}{c}{ Empiric frequencies, person } & \multirow{2}{*}{ Total } \\
\cline { 2 - 3 } Levels & Control group & Experimental group & 61 \\
\hline Passive-reproductive & 24 & 32 & 72 \\
Active-research & 38 & 34 & 52 \\
Intensive-creative & 24 & 28 & 12 \\
Analytical-reflective & 5 & 7 & 197 \\
Total & 96 & 101 & \\
\hline
\end{tabular}

With the $\chi^{2}$ criterion we have proved the uncertainty of the differences in the level of the research competence formation $\left(\chi_{\text {ex }}^{2}=0.88\right.$ at $\chi_{\text {con }}^{2}=7,815(\alpha=0,05)$. This has allowed us to start the forming stage of the experimental work selecting the experimental group at random.

At the forming stage of the experiment we introduced the academic support of the foreign language learning curriculum for the students in economics into the educational process of higher school. The provided academic support aims at the formation of the students' research competence and includes a program, a textbook for the students, a manual for the teachers, which covers the main provisions of the research competence formation among the students of economic specialties in the process of learning a foreign language in higher professional educational institutions, as well as provides guidelines for planning and organization of the educational process.

The submitted in the present research the teaching and methodical support as distinguished from the traditional one includes: 1) the topics concerning the basic provisions on execution of a scientific paper, book reviews, articles, course and diploma projects: "A Report Discussion", "A Report Structure", "A Conference Organization"," The review and article structure and content", "The Research project planning" etc.; 2) the topics functioning in the scientific field of the professional activity of the specialists in economics, namely: "A scientific research in economics", "Scientific cooperation", "Modern tendencies in the development of the economic science and modern technology," etc..; 3) the topics affecting students' grant winning: "A Student's Portfolio", "How to win a grant?", "The Paperwork for international programs and grants," etc.; 4) the topics used in business correspondence and professional communication of the future specialists in economics, in particular: "The Company (legal status, form, type, structure)", "Business and Finance", "Foreign trade contract", "Import-Export", "The Rules of Business Conduct", "Business Correspondence" and others; 5) the topics including national and foreign experience of the economists' professional activities: "The Economist of the Year", "The Foreign Market Leaders", " The World Business News", "The Market News", etc; 6) the themes guiding future economists to study throughout their lives: "The internship abroad", "The Master's program", "The Postgraduate study", "The Doctorate" and others.

\section{Discussions}

Analysis of psychological and pedagogical literature demonstrates that many Russian researchers describe pedagogical technology by the following features: algorithmics, manageability of pedagogical process, correcting (the possibility of feedback), visualization (the ability to use a variety of teaching tools), economical efficiency (including, on the one hand, strict control of the sacrificial time and mastery of a faculty member, and, on the other hand, the consideration of expired tools) (Bespalko, 1995; Klarin, 1989; Talyzina, 1986; Chernilevsky, 2002; Masalimova et al., 2014).

Analysis of psychological and pedagogical literature shows that different authors identify different stages and phases of pedagogical technology. V.S.Bezrukova highlights the following procedure of a faculty member activity as a technology of pedagogical designing: 1) the analysis of the designing object; 2) the choice of designing form; 3) the theoretical support of designing; 4) the methodological support of designing; 5) the spatiotemporal support of the project; 6) the legal support of the project; 7) the development of the project; 8) the selecting system-forming factor; 9) the establishment of relationships and dependencies of the components; 10) the paper writing; 11) the quality control of the project; 12) the mental experimentation of the project appliance; 13) the expert evaluation of the project (Bezrukova, 1994). 
N.Y. Postalyuk highlights the following set of phases of the pedagogical designing technology. They are generalized in units of designers' activity. The analytical unit: the first phase is the analysis of the situation. The conceptually-predictive unit: the second phase is the conceptualization; the third phase is the problem formulation; the fourth phase is the development of project ideal. The unit of constructivization: the fifth phase is the project schematization; the sixth phase is the object constructivization. The goal-setting unit: the seventh phase is the pedagogical design formulation; the eighth phase is the goal-setting. The procedural-technological unit: the ninth phase is the activity planning and programming. The unit of resources provision: the tenth phase is the resources analysis; the eleventh phase is the evaluation of project commercial attractiveness and its competitiveness in the educational market. The project management unit: the twelfth phase is the creation of project management system (Postalyuk, 1997).

It should be noted that the designing foreign language teaching content involves not only the implementation of successive stages and phases of designing activity, but also the use of scientific methods of its selection. Thus, B. S. Gershunsky believes that the research aimed ultimately at the selecting the teaching material must undergo a series of stages: the first is goals substantiation; the second is the prognostic selection of teaching content; the third is the teaching content classification; the fourth is the qualification characteristics, curricula and syllabus development; the fifth is the operational correcting of program documentation (Gershunskii, 1980).

The studies of N.A. Chitalin the technology of teaching content designing also includes five stages: 1) the modeling of specialist professional activity; 2) the array determination of qualities necessary for a successful professional activity and for systematization of knowledge, skills and personal qualities; 3 ) the teaching content structuring for educational, special and professional; 4) the objective systematization of educational content; 5) the teaching material formation (Chitalin, 1993).

Analysis of the literature allows us to conclude that the technologies of teaching content designing proposed by different scientists are of great interest for our research. However, they are designed without including research competence forming.

\section{Conclusion}

Therefore, in the submitted technology of forming the students' research competence in the process of learning a foreign language the developed design stages are universal and can be used in the formation of the students' communicative competence, while the design steps are particularly aimed at developing the research competence of the students in the process of learning a foreign language.

The performed experimental work on the implementation of the developed technology stated the improvement of the research competence formation of the students, which generally proves our hypothesis.

\section{Recommendations}

Basing on the results of the research it seems challenging to consider the issue of the research competence formation of the students of secondary and higher education institutions not only in the process of learning a foreign language, but also while studying other disciplines, as well as fostering methodological culture among the teachers of the "Foreign Language" discipline.

However, projecting these issues has not yet been carried out for the purpose of forming the research competence of the students in the process of learning a foreign language.

\section{References}

Berezhnova, E. V., \& Krajewski, V. V. (2006). Fundamentals of teaching and research activities of students: Monograph (p. 128). Moscow. Academy Press.

Bespalko, V. P. (1995). Pedagogy and advanced technology training (p. 336). Publishing House of the Institute of Professional Education Russian Defense Ministry. Moscow.

Bezrukova, V. S. (1994). Pedagogy: a textbook for engineering and pedagogical skills (p. 338). Ekaterinburg.

Bim, I. L. (2005). Modernization of the structure and content of language education. Foreign languages at school, 8, 2-6.

Chernilevsky, D. V. (2002). Didactic technology in higher education: Textbook (p. 437). Manual for schools. UNITY-DANA Press. Moscow.

Chitalin, N. A. (1993). Designing educational content. Specialist, 7, 31-36.

Gershunskii, B. S. (1980). Prediction of learning content in the colleges (p. 144). Graduate School Press. Moscow. 
Giniatullin, I. A. (1990). Independent work on the practical course of foreign language. Foreign languages in school, 1, 16-17.

Karpov, S. A. (2004). Science education in the modern school. Education, 9, 47-56.

Klarin, M. V. (1989). Educational technology in the educational process: The analysis of foreign experience (p. 80). Knowledge Press. Moscow.

Lopatina, O. V. (2009). Foreign technology foreign language teaching students language high schools. Kazan Pedagogical journal, 7-8, 163-170.

Lopatina, O. V., \& Ratner, F. L. (2011). Component composition and criteria of formation of the research competence of students in the process of learning a foreign language. Education and self-development, 1, 83-90.

Masalimova, A. R., Ikramova, G. D., Shaidullina, A. R., Gubaidullina, G. T., \& Apraksina, N. D. (2014). Distant in-company foreign language learning involving university student-tutors. American Journal of Applied Sciences, 11, 1123-1127. http://dx.doi.org/10.3844/ajassp.2014.1123.1127

Morozova, N. N., \& Fadeev, I. M. (2007). Model research competences of the person as the basis for the quality management of research activities in the university complex. University Management: Practice and Analysis, 5, 43-51.

Obukhov, A. S. (1999). Research activities as a method of forming a worldview. Education, 10, 158-161.

Postalyuk, N. Y. (1997). Basic concepts of logic and design of regional educational systems (Problems of continuing professional education: regional aspect). Proceedings of the Regional Scientific and Practical Conference (p. 224). Press Service. Moscow.

Talyzina, N. F. (1986). Theoretical Foundations of the model development specialist (p. 65). Moscow.

Voivoda, E. V. (2009). Internet-based technologies in teaching foreign languages. Higher Education in Russia, 9 , $110-114$.

\section{Copyrights}

Copyright for this article is retained by the author(s), with first publication rights granted to the journal.

This is an open-access article distributed under the terms and conditions of the Creative Commons Attribution license (http://creativecommons.org/licenses/by/3.0/). 